\title{
Neither Heimat nor Exile: The Perception of Paris as a Historical Blind Spot in Three Israeli Novels
}

\section{In Parallel}

For the last three centuries, Paris has attracted writers as a city to live and write in. Among the French literary greats are Honoré de Balzac, Charles Baudelaire, Victor Hugo, Marcel Proust, Jean-Paul Sartre, and Simone de Beauvoir. Among the long list of foreign writers who came to the French metropolis by choice or as exiles are Heinrich Heine, Rainer Maria Rilke, F. Scott Fitzgerald, Gertrude Stein, Ernest Hemingway, as well as the émigré group of Russian poets called the Paris Note, which included writers like Georgii Adamovich, Anatolii Shteiger, and Lydiia Chervinskaia. ${ }^{1}$ Apart from providing a physical home, the French metropolis has also long served as the object of literary fascination, and though Paris never regained the crucial role it played during les années folles, its image and appeal remain vibrant for many whereby the reflections of Parisian natives on the city are rather ambiguous compared to numerous outside perspectives. ${ }^{2}$ Yet, for all of Paris's popularity in various literary circles, the city played a smaller role in the history of Modern Hebrew fiction and poetry before World War II, overshadowed by the great centers of Modern Hebrew literature such as Odessa, Warsaw, and Berlin. Nonetheless, in the 1920s, as the city's role and importance in the modernist and avant-garde art scene reached its apogee, Hebrew poets like Rachel Bluwstein, Zalman Shneur, David Vogel, Nathan Alterman, Avraham Shlonsky, and Yocheved Bat-Miriam, arriving from Eastern or Central Europe,

1 Johannes Willms explains that the influence and importance of Paris has not been diminished over the centuries. Whereas cities like Florence, Prague, or Rome lost their influence over time that of Paris grew even stronger. The crucial factors for this development were the increasing centralization of France and the power of the monarchy, hence its peak in the nineteenth century when it became the informal capital of Europe. See Johannes Willms, Paris. Hauptstadt Europas 1800-1914 (Munich: C.H. Beck, 2000), 8. For a deeper analysis of the conception of home and exile by Russian émigrés, see Maria Rubins, "The Diasporic Canon of Russian Poetry: The Case of the Paris Note," in Twentieth-Century Russian Poetry. Reinventing the Canon, ed. Katharine Hodgson, Joanne Shelton, and Alexandra Smith (Cambridge: Open Book Publishers, 2017).

2 A point noted by several essays in the Yale French Studies special issue on Paris in Literature, edited by Joseph H. McMahon (New Haven: Yale University Press, 1964). 
or from Eretz Israel, did write in and about the city on the banks of the Seine. ${ }^{3}$ Importantly, throughout the second half of the twentieth century, Israeli writers like Yehoshua Kenaz, Yaakov Shabtai, Moshe Ben-Shaul, Haim Gouri, and David Shahar have traveled to Paris to live, write, and find inspiration there. Although they did not always write specifically about Paris, their works are often filled with allusions to French culture, quotes from French poems, chansons, or characters who dream of studying in the City of Light.

In this chapter, I would like to explore how the longing for and imagination of Paris functions in three Israeli novels, A.B. Yehoshua's Five Seasons (מולכו, 1987), Judith Katzir's Matisse Has the Sun in His Belly (למאטיס יש את השמש בבטן, 1995), and Lizzie Doron's On the Brink of Something Beautiful (התחלה של משהו יפה השמה, 2007), thus taking into consideration not only canonical authors of the generation mentioned above, but the next generation as well. These novels are, moreover, very diverse in their literary ambition, language and style as well as their narrative content, yet they all include short but pivotal episodes featuring a couple's journey to Paris. It is my intention here to explore how Paris serves as a space for desire and longing in the novels. As it will become clear, Yehoshua, Katzir, and Doron, through various means, describe Paris as the metropolis of European high culture embodying traditional French lifestyle and the ideal of the European "capital of the nineteenth century." In this depiction, Paris appears as if untouched by the historical events of the twentieth century. The characters in these three novels do not only travel to Paris to experience personal happiness the sometimes kitschy motif of the City of Love is reflected in various ways in all three texts - but also to find a place in Europe that is seemingly devoid of the traumatic experience of the Holocaust, unlike Austria, Germany, or Poland. While all of the narrators mention other European places, and some characters even continue their voyage eastward (into the darkness of the past), Paris is still imagined as the ideal, Western European city. Given the breach of civilization, the extermination of European Jewry, and the Israeli perspective of the three novels, such a presentation of Paris tells a curious story. It is thus my intention here to elaborate on the city's depiction in relation to other European realms in the context of the characters' relation to Holocaust memory. In other words, it is my aim to discuss how Paris is imagined by the narrators and in so doing to point to how Paris, in these works, emerges as an ahistorical blind spot.

3 For further elaboration on this topic see Yuval Ben-Atiya, העבות בעונות פריזאיות.' דיוקן פריס בשירה "'Parisian Pictures.' The Image of Paris in Hebrew Poetry between the Two World Wars"), M.A. thesis, Tel Aviv University, 2002. 
According to the textbook on ophthalmology by Fritz Hollwich, the blind spot is "an area of complete blindness in the visual field." ${ }^{4}$ In a similar way, the narrators and characters in the chosen novels do not visualize European Jewish history, and especially the Holocaust, when directing their gaze to Paris. This is surprising since Paris is the very opposite of an ahistorical place. Only typing "Paris" and "Memory" into a search engine reveals pages of Holocaust-related memorials and ceremonies in and around the French capital. Even when leaving the Nazi occupation and the deportation of Parisian and French Jews aside, Paris abounds with lieux de mémoire of French history, such as the Arc de Triomphe and the Bastille, to name but two. Moreover, the city itself is listed in the collection of Pierre Nora as a lieu de mémoire under the category "identifications," meaning that Paris shapes French identity and memory of the society and nation. ${ }^{5}$ Furthermore, memory also plays a crucial role when looking at Paris from a non-French perspective. The volume Paris, From the Image to Memory (Paris, de l'Image à la Mémoire $)^{6}$ focuses on the perception of the city through the eyes of foreigners - mostly from neighboring European countries. In the introduction, MarieChristine Kok Escalle writes that our image of Paris is formed by the memory we inherit: "This heritage is loaded with emotions that provoke admiration or love, anxiety or hostility; it is a 'memory' that links the place with a history and a symbolic meaning; it is a set of mental and emotional representations developed from images which are occasional or involve a longer period."7 However, as it will become clear in the following pages, Paris is not only a place formed by memory, but it can turn into a realm where the latter is avoided and ignored. Phrased differently, the perception of Paris as outside the natural flow of time, leads to the depiction of an urban realm deprived of a tragic chapter in history. Unlike Rome and Jerusalem, Paris's reputation is less "eternal”; more saliently, the City of Light is neither an ancient city nor loaded with religious meaning. Furthermore, perceiving Paris as the European capital of the nineteenth century, an image that seems to persist one way or another, first and foremost focuses on

4 Fritz Hollwich, Ophthalmology: A Short Textbook, trans. Frederick C. Blodi, 2nd ed. (Stuttgart/ New York: Georg Thieme Verlag/Thieme Stratton, 1985), 7.

5 Pierre Nora, Les lieux de mémoire (Paris: Gallimard, 1997).

6 Marie-Christine Kok Escalle, ed., Paris, de l'Image à la Mémoire: Représentations Artistiques, Littéraires, Socio-Politiques (Amsterdam/Atlanta: Rodopi, 1997).

7 “Cet héritage est chargé d'émotions, que celles-ci provoquent l'admiration ou l'amour, l'angoisse ou l'hostilité, il est 'une mémoire' qui associe à un lieu une histoire et une signification symbolique; c'est une ensemble de représentations mentales et affectives élaboré à partir d'images, que celles-ci soient ponctuelles ou qu'elles concernent une durée plus longue.” Marie-Christine Kok Escalle, Introduction to Escalle, Paris: De l'Image à la Mémoire: Représentations Artistiques, Littéraires, Socio-Politiques, 1. 
Paris's cultural impact and the development of modernist art and literature and not political power - which France was already losing.

In undermining the status of Paris as a lieu de mémoire, or put another way, in perceiving an idealized urban realm that is a product of the lasting picture of a life-celebrating Parisian culture that emerged in the nineteenth-century capital of Europe and the modern avant-garde scene of the 1920s, the novels discussed here thus reveal a historical blind spot. The fact that all three were published from the 1980s onward, a time by which the Holocaust had become increasingly present in the Israeli public discourse, makes this blind spot all the more noticeable, and unlike places in Austria, Germany, and Poland, Paris serves as neither Heimat nor exile, but rather as an artificial vanishing point from reality. Marcy E. Schwartz describes a similar phenomenon in Latin American literature, where, when it comes to Europe, Spain and Portugal are mostly excluded from a positive depiction since they provoke memories of the dark time of colonialism. Paris, on the other hand, becomes, according to Schwartz, the European model of urbanness that influences the conceptualization of urban identity especially in, but also beyond literature. ${ }^{8}$

As I have mentioned above, Paris as such is obviously not ahistorical, nor is the perception I propose in this context necessarily modernistic. Nevertheless, first, a modern understanding of history is necessary to identify the lack of discussion on one particular chapter of history that is emotionally very close to the protagonists; and second, a specific modern concept plays a great role in exploring the city: strolling around. Thus, Paris's importance for modern literature lies not only in its ability to inspire or in the setting it offers; indeed, the very experience of observing and wandering its many streets and passages turns into a literary figure itself. One of the best-known representations of this activity is the concept as developed by Walter Benjamin, a thinker who also promoted the idea of Paris as the European capital of the nineteenth century. Interestingly, he explored this figure through Baudelaire, one of the key poets of the modernist Parisian literary scene. However, the flâneur was conceptualized over time from different perspectives and it could be argued that the fictional characters from the novels I am going to address are not flâneurs simply because they are visitors and tourists. ${ }^{9}$ And still, strolling is important for how they perceive Parisian space.

8 Marcy E. Schwartz, Writing Paris: Urban Topographies of Desire in Contemporary Latin American Fiction (Albany: State University of New York Press, 1999), 2-4.

9 See Victoria E. Thompson, “Telling 'Spatial Stories': Urban Space and Bourgeois Identity in Early Nineteenth-Century Paris,” The Journal of Modern History 75, no. 3 (2003): 523-56. 
Although Michel de Certeau states that "to walk is to lack of place,"10 the characters make the cityscape their own through walking, as will become clear later. But, although it seems as if they belong there for a certain amount of time in one way or another, the spiritual homeland, the imagined Paris, that is neither Heimat nor exile, evokes a vague longing and yearning, oftentimes for that which is not. De Certeau moreover elaborates on what he calls the Wandersmänner and their subjective use of the cityspace: "These practitioners make use of spaces that cannot be seen; their knowledge of them is as blind as that of lover's in each other's arms." 11 The blind spot that has been described above is caused by willingly not seeing or willingly not referring to a certain aspect that is part of the place's history, but by doing so, the place itself turns into a blind spot; it is characterized by the presence of an absence to put it in de Certeau's terms one more time. ${ }^{12}$ He moreover emphasizes that the depiction depends on what unfolds before us: "Places are fragmentary and inward-turning histories, pasts that others are not allowed to read, accumulated times that can be unfolded but like stories held in reserve, remaining in an enigmatic state, symbolizations encysted in the pain or pleasure of the body." ${ }^{13}$ This individual perception of space is what also constitutes a spiritual homeland that is neither a historicized Heimat, nor an ahistoric exile. Rather, the fact that it is spiritual gives way, in my understanding, to a personally transformed space that is perceived subjectively according to the needs of the perceiving individual. How this is dealt with in the three fictional narratives will be the subject of the following discussion.

\section{Paris in White and Grey: A Winter Voyage}

The novel Five Seasons, published in 1987, is among a number of transitional texts that point to important changes in A. B. Yehoshua's writing, moving as he did from symbolism to realism, and approaching new topics in the process. ${ }^{14}$ The plot of Five Seasons revolves around the protagonist, Molkho, in the first year

10 Michel de Certeau, The Practice of Everyday Life, trans. Steven Rendall (Berkeley/Los Angeles/London: University of California Press, 1984), 103.

11 Ibid., 93.

12 Ibid., 108.

13 Ibid.

14 Gilead Morahg gives a short summary of the discussion among critics on A. B. Yehoshua's stylistic transition before elaborating upon the deficits of this thesis and explaining why his style is to be seen not as realism but rather as realistic symbolism. Gilead Morahg, "Reality and Symbol in the Fiction of A. B. Yehoshua," Prooftexts 2, no. 2 (1982): 179-96. 
after his wife's death from a long and terminal illness. With her passing, Molkho needs to find his own, and certainly a new, place in the world. ${ }^{15}$ During the year of mourning he travels twice to Europe. The episodes set in Paris are rather short but essential to Molkho's stages of grieving and his return to a life by himself without sickness and death; moreover, they shed light on the relationship he had with his late wife.

Molkho comes to Paris, the city he had visited with his wife already three times. Therefore, the city is no stranger to him. Yehoshua, who himself lived in Paris from 1963 to $1967,{ }^{16}$ about two decades before he wrote the short episode on Molkho's voyage to the city, does not project idealized visions of Paris onto his protagonist. Moreover, Molkho does not just come to Paris to escape his reality back home or for a restorative vacation. He returns in January, four months after his wife passed away, to see once more the place they both loved: "Three times he and his wife visited Paris, and each time they reassured themselves again of their common love for this city." ${ }^{17}$ Yehoshua appeals thusly to the trope of Paris as the City of Love, but suggests that it was their common love for the city itself rather than their love for each other that draws Molkho back. The memories of their trips make Paris unique for Molkho, and the narrator emphasizes that he now travels alone on this his fourth visit. ${ }^{18}$ The trip to Paris thus marks the beginning of Molkho's new life. Unlike his time in Vienna and Berlin, his stay in Paris is not filled with dark, non-personal memories, but rather with pleasant memories connected to his wife and their former visits to the French capital.

The plans for Molkho's journey to remember are disrupted from the very beginning. First, he had planned to stay at the same hotel in which he had stayed with his wife on their last visit, but her cousin insists on hosting him at her home. Molkho cannot help but feel that their motivations are emotionally complicated: "As if they decided to compensate him with an overload of warmth, out of guilt

15 A. B. Yehoshua's thoughts about this novel were influenced by the death of a good friend of his wife who passed away while he was writing. The couple was in the United States, and when they came back, Yehoshua's wife went to see her friend's husband. What she told Yehoshua afterwards had an impact on how he wrote and described the scenes around the death of Molkho's wife. Bernard Horn, Facing the Fires. Conversations with A. B. Yehoshua, (Syracuse: Syracuse University Press, 1997), 67-68.

16 Nitza Ben-Dov, "על א"ב יהושע ויצירתו" (On A. B. Yehoshua in His Work), in מבטים מצטלבים: עיונים ביצירת א"ב יהושע (Intersecting Glances. Studies of the Work of A. B. Yehoshua), ed. by Amir Banbaji, Nitza Ben-Dov, and Zavi Shamir (Tel Aviv: Hakibbutz Hameuhad, 2010), 9.

"שלוש פעמים ביקרו הוא ואשתו בפאריז, ובכל פעם אישרו לעצמם מחדש את אהבתם המיוחדת לעיר הזאת." 17 (1987), Abraham B. Yehoshua, מולכו (Tel Aviv: Hakibbutz Hameuhad, 1987), 79.

18 Ibid. 
that they did not come to the funeral and sent only a telegram." ${ }^{19}$ The guilt not only disturbs the purity of Molkho's commemoration, but also turns the journey to remember her life into a journey to remember that she died: when she was alive, they had always stayed at hotels. Molkho's relationship to his wife's cousin is ambiguous. Although he feels distant at first and a bit disturbed in his plans, he enjoys the busy mornings, the loud French-speaking family, and the chaos in the house - a stark contrast to the silence he had experienced at home with his dying wife in the months before. ${ }^{20}$ Although Molkho had never lived in Paris, he nevertheless represents the "anti-tourist": he speaks the language, even if his French is not good enough to discuss with the Parisian relatives all the medical details around his wife's death. ${ }^{21}$ Moreover, he chooses to visit only one historical site, Versailles, a site that is neither directly connected to the Holocaust nor to his or his wife's personal history. Furthermore, this lieu de mémoire is situated outside of the city itself. In other words, the little historical memory Molkho encounters during his visit is placed at the outskirts of Paris and in the periphery of his perception.

The cold weather symbolizes once more his position as a non-tourist; for example, the beautiful gardens of Versailles are covered in snow and the palace appears inhospitable. But the meteorological circumstances reflect more than just the regular continental European weather one must expect in January: "The next morning the wind became stronger and the temperatures fell and the announcers of the weather forecast on the radio had an alarming tone ... The people at the tables around him talked with enormous excitement about the weather."22 The cold weather has a rather positive effect on Molkho. Not only does he feel hungry after his frosty tour of Versailles, ${ }^{23}$ but also the news and the constant conversations about the snowstorm are a nice alternative to the news in Israel. As Risa Domb has observed, "the renewed encounter with Europe triggers admiration and attraction as well as hostility and repulsion. Some protagonists escape to Europe and others from Europe, but in both cases Europe never serves as just a tourist's sightseeing spot abroad but as a world which stands in total contrast

”כמו מתוך אשמה על שלא באו להלוויה ורק שלחו מיברק החליטו לפצות אותו עכשיו בחמימות יתרה." Ibid. 20 Ibid.

21 Ibid.

"למחרת בבוקר גברה הרוח והטמפרטורה ירדה מאוד, ולמגישי חדשות מזג-האוויר ברדיו היה טון מאיים. [...]

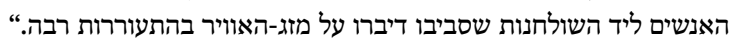
Yehoshua, מולכו, 80.

23 Ibid. 
to Israel." ${ }^{24}$ Moreover, the snow blankets the scene in a peaceful atmosphere: "Around midnight when they left the opera, they were surprised by a clear sky and the whole city rested under a white and thick layer of glowing snow."25

As already mentioned, Molkho does not visit Paris for sightseeing. The first morning and reencounter with the city is therefore described against the background of his hosts' daily routine: “They dropped him off to stray under the grey sky in the Latin quarter, on the boulevards, at places he loved, known to him from previous travels, and when the huge stores opened he went from one floor to another to check the prices and to collect initial ideas for the presents he needed to bring to his children." 26 The department stores as well as shopping for presents are rather opposed to the Benjaminian arcades and the practice of strolling. It is Molkho's first day in Paris and he seems a bit lost. Unlike regular tourists, he does not have a plan for which site to visit first and which should follow it; and although shopping for gifts, especially souvenirs, can be rather touristic, most people would explore the city first, something Molkho does not feel the need to do because he already knows his way around. Moreover, rather soon he gets back to wandering around and because Molkho does not have a special spot that he wants to visit first, his walks seem aimless. Even a few days later: "[He] walked around in the city, between heaps of snow despicable as long as the sky shone in a callous blue, he delved into the small streets behind the opera house..."27

Five Seasons is the first transitional text in Yehoshua's oeuvre that suggests his growing interest in Mizrahim in Israel and mizrahi identity. ${ }^{28}$ In Molkho's case,

24 Risa Domb, "Home and Abroad: Israel and Europe in Hebrew Fiction of the 1980s," Israel Affairs 1, no. 2 (1994): 326.

"לקראת חצות, כשיצאו מן האופרה, הופתעו למצוא שמיים נהירים והעיר כולה נחה תחת מעטה לבן ועבה של 25

שלג זורח." שראת

Yehoshua, מולכו, 81.

"הורידו גם אותו לשטט תחת שמיים אפורים ברובע הלטיני, בבולבארים המפולשים, במקומות שהיו מוכרים

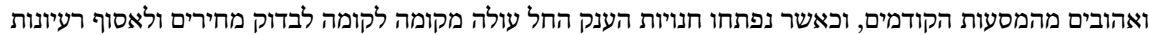

Ibid., 79-80.

ראשונים למתנות שיצטרך להביא לילדים, וכשריו.

"] [הוא] הסתובב בעיר, בין ערימות השלג שנעשה מסואב ככל שהשמיים הבהיקו בכחול בוטה. הוא העמיק 27

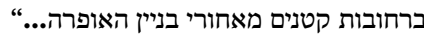

Ibid., 83.

28 At this point, I would like to clarify that I do not use the term Mizrahi in this context as referring to Jews who immigrated to Israel from the Arab countries and North Africa in the 1950s. This is neither the background of Molkho the fictional character nor of Yehoshua the author. The fact that this explanation is needed already hints at the difficulties that come with these terminologies. For obvious reasons, the term Oriental is problematic as well as is Sephardic, which does not only refer to the Jews whose ancestors fled from the Iberian Peninsula, but describes also a religious tradition. 
his deep connection to his Levantine roots influences his Israeliness, which is defined, inter alia, by the land and its geographical location in the Levant and decidedly not in Europe. I suggest that we can thus read Yehoshua's Paris episode within the context of the discussion about a Levantine identity.

Bernard Horn and A. B. Yehoshua discuss this issue in the conversations Horn published and come to the conclusion that Molkho's identity is stable and that neither the fact that his wife was of European origin, nor the fact that he travels to Europe and is even familiar with Paris as a European city lets him merge with the Parisian society or make him question where he comes from and belongs to: "In Five Seasons, though the story is told in the third person, the point of view is rigorously Molkho's, and never is there any question of the borders of identity. Rather, as the novel moves from Israel into France, Austria, and Germany, we stand well within the human borders of 'Molkho, Israeli,' and, as he struggles with his private identity as an adult male and a lover, he has the sort of stability and particularity of the characters of nineteenth-century Russian literature." ${ }^{29}$ As opposed to his Berlin-born wife, Molkho identifies solely with the realm of the Levant and feels a deep connection to the land and its tradition. He struggles as a man and husband, but feels rooted in the land his Sephardic forefathers already lived in. Whereas he just travels to Europe in order to assure that he has a home, many others like his wife and mother-in-law have been uprooted from the old continent. The fact that they found a place in Israel after their flight from Germany does not lead automatically to the same feeling Molkho has about his Levantine homeland. They are still connected to European history and culture and see it as part of their own identity that takes up time and space in their daily life. Moreover, it is his wife's cousin whom they visit in Paris, whereas Molkho does not have any family ties in Europe. Nevertheless, the fact that Paris enables another encounter for him and his wife that does not take place either in her former homeland or in the land they lived in and wherein Molkho sees his roots, makes this city a spiritual homeland to Molkho that does not claim to be his Heimat.

France and Paris can be seen as a cultural space of transition from Europe to the Levant and therefore as a connecting factor between Molkho and his wife. In her writings, Jacqueline Kahanoff emphasizes the influence of French culture on Levantine identity. She describes France as "a Latin nation, which by means of the church had inherited the essence of cultured Levantinism as it was embodied in Byzantium." ${ }^{30}$ Israel is seen by Kahanoff as the "ambivalent Levantine,"31

29 Horn, Facing the Fires, 85.

30 Deborah A. Starr, Sasson Somekh, eds., Mongrels or Marvels. The Levantine Writings of Jacqueline Shohet Kahanoff (Stanford: Stanford University Press, 2011), 182.

31 Ibid., 193. 
since it is geographically located within the Levantine realm, but is, through Zionism, strongly based on European thinking and conceptualization. This characterization can be also applied to Paris, which is geographically located in Europe but has a strong - although partly negative, due to its colonial history lingual and cultural connection to the Levant. Like Paris, the Levant is a realm of boundaries, a realm where one meets the other. France is, moreover, situated on the Mediterranean, but Paris is perceived as a, or even the, European city; or in other words, it is the Europe of the Levantines. Thus, Molkho is not looking for a new Heimat in Paris, but he does not feel as distant and as non-European in the capital of this Mediterranean country as he does in Berlin and Vienna. This might not be as strongly connected to the Holocaust as we think, but again to the fact that Molkho speaks the language of Paris, which is also widely spoken in the Levant.

The fact that Molkho has no personal or family history in Europe allows him to have a fairly "neutral" attitude about the old continent and its past. This is reflected in the author's own claim that his approach toward the Holocaust was rather intellectual and less emotional since he is an Oriental Jew and his family was not directly affected. ${ }^{32}$ Horn does recall in their conversations his own family history and Yehoshua consequently elaborates on how personal and family history effect the perception of specific places and cities in Europe:

Yes, when Jews deal with their past in Europe now - imagine, for example, a Jew who goes back to Russia: he isn't concerned with his village as a geographical place; he is concerned with the community that was, let's say, in Lvov or in Lida or your father's Sambor.

When he goes back, he deals with families and with the structure of human relationships, but he does not see Vilna, for example, first of all as a place, in a geography, near a river, near all those things that make Vilna's smells and colors whatever they are. ${ }^{33}$

Molkho's own experience is juxtaposed to what Yehoshua describes in these lines as a characteristic encounter of Jews who had family members that fled from Europe during World War II or perished in the Holocaust. The encounter he has is not one with the historical past, but rather with his and his wife's personal history. Even in Berlin where he looks for the house his wife was born in, there remains a distance between Molkho and the place. Nevertheless, as Risa Domb emphasizes, the encounter with Europe is for most literary characters not a "new" one - not even for Molkho as I would like to add. ${ }^{34}$

32 Horn, Facing the Fires, 129.

33 Ibid. 106.

34 Domb, "Home and Abroad," 326. 
For Molkho, Paris is indeed a contrast to Israel - also on a personal level, as are the other European cities he visits. But, it is first and foremost in the French capital that he reencounters family life while staying with his wife's cousin, her husband, and their two little children, a family life that seems to differ enormously from the one he led with his dying wife. The French family's lively and chaotic daily routine contrasts with his and his wife's months-long wait for death. The children do not only stand at the beginning of their own journey, they symbolize Molkho's new journey, his new beginning.

Although the young family brings him back to life, Molkho visits Paris primarily to stay in the past. He chooses Paris to say his final goodbyes and only in leaving Paris behind can he move on; Paris is Molkho's closure. Molkho learns how to be by himself again, he walks alone in the rather grey and cold winter streets, but he can still come home to a warm and welcoming environment. For all its dreary weather, Paris reminds him of the love he shared with his wife. It is not associated with an idealized picture of Europe as the elderly home where his mother-in-law lives and in which Amir Banbaji identifies the "Weimar idyll." 35 Nevertheless, Molkho is not confronted with the historical past either and remains in the comfort zone of his personal memories.

\section{Paris of Art, Literature, and Music}

Personal memories are what the young protagonist in Judith Katzir's Matisse Has the Sun in His Belly who was, like Molkho, in Paris before, still creates, and she does so on the visit discussed in the following. In contrast to Molkho and his wife, on her prior visit, art student Rivi saw only the Eiffel Tour and the Louvre while on an organized tour of Europe. ${ }^{36}$ The second visit that is recalled in detail in the novel is again integrated into a longer tour, but nevertheless she and her lover Yigal manage to see more than she did the last time.

Judith Katzir was born in 1963 in Haifa and started publishing novellas and novels in the late 1980s during the "female revolution," when she gained critical attention together with other women writers including Zeruya Shalev and Michal Govrin. "[A]lthough entirely different from each other in tone, style, and literary sensibilities, these authors undermined the 'oedipal masterplot' through

35 "האידיליה הוויימרית." ניות"

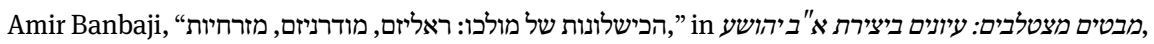
ed. by Amir Banbaji, Nitza Ben-Dov, Zavi Shamir (Tel Aviv: Hakibbutz Hameuhad, 2010), 173-194. 36 Judith Katzir, למאטיס יש את השמש בבטן, (Tel Aviv: Hakibbutz Hameuhad, 1995), 50. 
a 'poetics of the body' and often focused on mother-daughter duos," writes Nili Gold, who identifies these poetics of the body in Katzir's descriptions of Haifa that appear in almost all her texts: "Haifa surrenders itself to the feminine voice of her native. The city of curvy bays, mountains, rounded treetops, and lush nature recalls in its contours the feminine body." ${ }^{37}$

In Matisse Has the Sun in His Belly, Rivi goes through the ups and downs of an affair with a married man with a child - Yigal. Throughout their relationship, they travel to Italy, France, Spain, and Egypt. Each country represents a different stage in their liaison, which continues until Rivi realizes that she will always come in second after Yigal's family. They split and thereafter only meet one more time after Rivi's mother dies from cancer. The novel is narrated precisely, even overloadingly, and there are few details of their personal and sexual relationship that remain vague.

Early in their relationship, Rivi and Yigal travel together to Europe. First, they spend some time in Italy before they finish their trip with a few days in Paris, where they live the romantic cliché. The city for lovers turns into a heterotopian space where they exist as an almost regular couple. In Italy, on the other hand, they had not yet entered into a clear routine, and in Spain their connection to each other suffers from its first ruptures. It is self-evident that their daily routine is even more complicated in Israel. Rivi's statement in a room full of Matisse paintings is therefore not surprising: "And I would like for the moment not to end, that we would stand together in front of all that red in the heart of Paris forever." ${ }^{38}$ However, not to move and to stay in the moment is contradictory to Rivi's regular behavior. She and Yigal do not calmly stroll and explore, but are driven by Rivi's excitement and restlessness:

[T]hey went by foot from their hotel in Saint Germain to the Centre Pompidou, and she rejoiced next to him like a foal, she stopped in front of every café and every shopping window, sticking her nose into every bakery and perfume and tobacco shop ... she was thrilled, wandered around among the paintings, not in order but according to what caught her eye, like she read books from time to time, from the middle, and from the beginning and from the end without patience. ${ }^{39}$

37 Nili Gold, “The Topography of the City and the Body: Yehudit Katzir's Haifa," Hebrew Studies 47 (2004): 282-83. For more on Katzir’s biography see Shay Rodin, "קציר יקסיר, יהודית הקשרים ed. Zissi Stavi, Yigal Schwartz (Or Yehuda: Kinneret, 2014), 813-14.

"ורציתי שהרגע הזה לא "יגמר, שתמיד נעמוד יחד בלב פאריס מול כל האדום הזה." 38

Katzir, Matisse, 51.

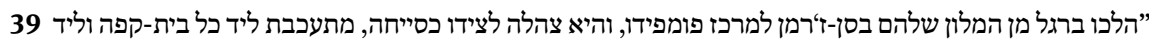

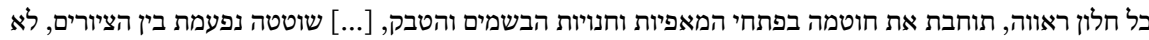

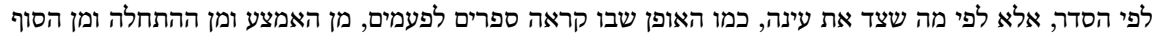


The frequent use of the conjunction "and" further increases the feeling of unrest. Rivi's excitement dominates the way their trip to Paris is narrated, from the beginning when she opens the window of their hotel room on the first morning. It is oddly described as a big "French window." ${ }^{40}$ The brightness that might come through that window is a link to Paris as the City of Light, but the scenery outside is neither flooded with light nor is it anything more than ordinary everyday life: "And she looked at the grey sky and at the roofs as dark as basalt, and then at the narrow and long street that twisted five floors under her, only two sanitation workers in orange jumpsuits were seen at six in the morning, and the lines of toy cars along the sidewalk, and a few men who entered and left a bistro on the corner." ${ }^{41}$ Nevertheless, the simple fact that Rivi is in Paris and that she watches this scene through a "French window" together with her almost child-like attitude to explore adds this scene to her particular perspective on Paris while remaining in the sanctuary of the hotel room and not participating in daily life.

Another sanctuary realm that is even more detached from daily Parisian life is the art scene they partly re-imagine for themselves. From an art historian's point of view, Rivi and Yigal stroll mostly in the post-World War II era. However, it is intertwined with the colorful 1920s represented by, for example, Brecht and Weill's Three Penny Opera they go to see together. Throughout the novel, it is mostly their beloved bookseller Golden who connects first Rivi but also Yigal to a bygone European world and culture. The text is full of nods to Stefan Zweig in general and his autobiography in particular. ${ }^{42}$ In The World of Yesterday, Zweig describes the Paris before the destruction by Nazi Germany as characterized by "the divine colourful, the blessed cheerful, the melodiousness and the unwittable blossom of this harmonic entity." 43

Ibid., 51.

באיזה חוסר סבלנות....

40 Ibid., 50.

41 ריק 40

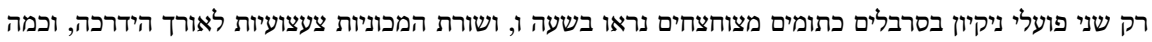

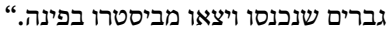

Ibid., 50.

42 For further elaborations on Golden the book trader and the references to Zweig's The World of Yesterday in Matisse Has the Sun in His Belly, see Judith Müller, "Auf der Suche nach dem letzten Europäer in Judith Katzirs Matisse hat die Sonne im Bauch - Eine israelische Nebenfigur aus einer Welt von Gestern," Germanica Revues. Regards croisés sur l'Europe et les voisins européens 56 (2015): 15-26.

43 "[D]as göttlich Farbige, das selig Heitere, den Schmelz und die unverwelkbare Blüte dieses harmonischen Gebildes." Stefan Zweig, Die Welt von Gestern. Erinnerungen eines Europäers 
In Matisse Has the Sun in His Belly, the rupture in the city's cultural life after Paris was occupied by the National Socialists is not mentioned. It rather seems as if the cultural life continued to flourish throughout the most catastrophic decades of modern European history. Rivi and Yigal go to the Picasso museum to see paintings of the Spanish-born artist from the early twentieth century through the decades after World War II. The couple sits in the Closserie de Lilas at the tables of people who shaped the culture in those decades like Ernest Hemingway, Jean-Paul Sartre, André Gide, and Gertrude Stein. Moreover, they visit the postmodern building of the Centre Pompidou that has "red and blue tubes gaping out its head as a periscope" 44 and was built only in the 1970s. The unsorted mix of styles, epochs, names of artists and works causes a rather blurry picture of what Paris might be, but the colorfulness and diversity help again to omit the memory of dark times.

However, Rivi recalls memories. First of all, she recalls her own, and she does so in Paris when she tells Yigal the story about her now-divorced parents and how they first met. Moreover, she "manages to extract memories" from Yigal. Leon I. Yudkin argues that, "Rivi looks both backward and forward; her memorialization is both recollection of the past and protection against the vicissitudes of the future." ${ }^{45}$ However, these are all personal and not historical memories connected to Paris. In fact, the French capital provides stability rather than a stormy and insecure history: "She walked through the narrow streets, dwelling near the windows of the galleries and the antique shops. I would be happy to live in one of these houses, she thought. Indifferent, great, with the assurance of centuries they rest on, and everything, stores and restaurants and people, moves with a by-theway refinement, without any effort, and the light is comforting in its greyness, not demanding, moderate." ${ }^{46}$ In sum, although Rivi and Yigal seem to live the cliché of the City of Love, they do not imagine the idealized nineteenth-century capital of Europe. Nevertheless, the long chain of places they go to, the paintings they see, and the names of French cultural personalities they talk about are a path to a blind spot. Although the same could be said about Italy, Spain, and Egypt, Paris

(Frankfurt am Main: Fischer Taschenbuch Verlag, 2012), 151.

"שצינורות אדומים וכחולים פעורים מראשו כפריסקופים." 44

Katzir, Matisse, 51.

45 Leon I. Yudkin, “Memorialization in New Fiction,” World Literature Today 72, no. 3 (1998): 489.

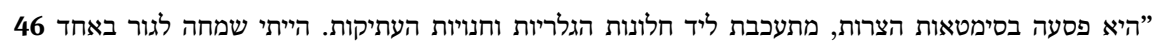

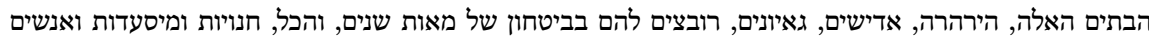

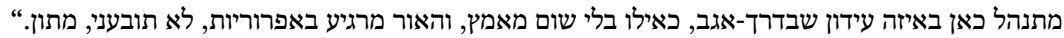
Katzir, Matisse, 56. 
remains unique since they reach a personal not only a historical blind spot in the French capital: they do not only seem to live the cliché; it is in Paris that historical time appears to stop - the old houses in their assurance of centuries and the red of Matisse paintings that invites Rivi to stay represent this notion.

\section{Paris of Love, Light, and Life}

For Amalia in Lizzie Doron's On the Brink of Something Beautiful, the past and especially the Holocaust is always present. Like the two other protagonists of the novel who grew up in the same neighborhood, she is the daughter of Holocaust survivors, as is the author herself. Lizzie Doron was born in 1953 in Tel Aviv. In the past years she has written about the Middle East conflict starting with Who the Fuck is Kafka (German, 2015), a novel which has not been published in Hebrew due to its content. This book in particular is highly critical of how Israeli society deals with the other and how it accepts or rather does not accept Jewish-Arabic encounters, friendships, and love. However, in the 1990s, Doron began her career as a writer of fiction about the second generation, thus joining other "second generation" writers like Nava Semel and Savyon Liebrecht. In that decade, the narrative of Israeli literature became more pluralistic - or in other words, the Zionist narrative was not the only one anymore, but rather one among many. It is therefore not a coincidence that female writers such as Judith Katzir and authors of the second generation like Lizzie Doron appeared during and after that change. Neither is it surprising that A. B. Yehoshua's narrative took into account the non-Ashkenazic point of view.

On the Brink of Something Beautiful is divided into three parts, each one dedicated to one of three children, Amalia, Hezi, and Gadi. The reader follows their problems as they live with their survivor parents and later follows their lives as adults, which are still influenced by what they and their parents experienced. ${ }^{47}$ For the purposes of our study, we will focus on Amalia and Hezi and a short episode in which they think about living together in Paris. They are both in their fifties; Amalia works at an Israeli broadcasting station and Hezi is a historian teaching at the Sorbonne. When Hezi comes home for his father's funeral, he hears Amalia on the radio and they agree to meet. A short time later, she travels to Paris to be with him: "Two weeks ago I landed at the Charles de Gaulle airport.

47 For an analysis and description of the trauma of the second generation and its impact on their behavior and daily life see Dina Wardi, Memorial Candles. Children of the Holocaust, trans. by Naomi Goldblum (London/New York: Routledge, 1992). 
Paris fits me, I thought." ${ }^{48}$ This simple thought shows the naiveté in Amalia's behavior. She does not really know if Paris fits her because she has never been there for any substantial amount of time. And, she does not know Hezi either. She remembers Hezi the child who lived next door to her, but she has never spent enough time with him to know him as a grown man. She is nevertheless convinced that he is committed to her and their future in the City of Love where she plans to marry him. However, Amalia never truly arrives in Paris although she lands at the Charles de Gaulle airport on the outskirts of the city. Hezi picks her up and instead of leaving the airport, he surprises her with tickets to Poland where they fly immediately in order to rebuild the former Heimat of their parents.

Traveling to Europe is a crucial issue in second-generation literature. In her study Past Present: Biography, Identity and Memory in Second Generation Literature, Iris Milner elaborates:

\begin{abstract}
Works of second-generation literature can be considered as travel literature in two different ways that often coexist in one single work. In a concrete form, as when the works describe a real voyage to specific geographical destinations which were not the places of killing and remembrance in Europe, or in a symbolic way - such as when the works focus on the mental, imaginary journey that is psychoanalytical in character, towards the bottoms of the archaeological piles that cover up a silenced past, and a repressed identity. ${ }^{49}$
\end{abstract}

For Amalia traveling to the geographical places in Poland triggers memories of a silenced past whereas her imaginary journey to Paris promises a new beginning. Connected by alliteration, Paris and Poland are presented as opposed poles. Although Hezi tries to convince Amalia that Kraków can be their new Paris, she cannot stop noticing the differences. After all, there is no Arc de Triomphe in Kraków, neither is there the Champs Elysée. ${ }^{50}$ Moreover, Kraków is dark at night in contrast to the City of Light, and the memories connected to Poland are even darker. Already before she arrives, the sheer thought of being in Poland makes Amalia sick: "For three hours I threw up into a bag and imagined my death under the sky of Poland." ${ }^{51}$ Her dramatic experience came partly from shock, since Hezi

”לפני שבועיים, אולי קצת יותר, נחתי בשדה התעופה שארל דה גול. מתאים לי פריס, אמרתי לעצמי." 44 , 48 , Lizzie Doron, התחלה של משהו יפולי אמרת (Jerusalem: Keter, 2007), 44.

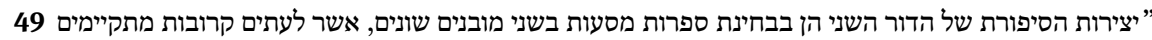

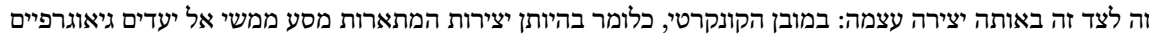

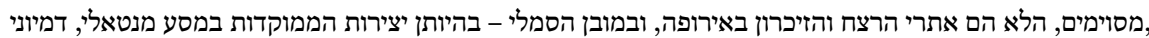

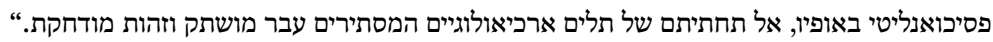
Iris Milner, קרעי עבר. ביוגרפיה, זהות וזיכרון בסיפורת הדור השנים מדוגים (Tel Aviv: Am Oved, 2003), 95-96. 50 Doron, Something Beautiful, 46.

"שלוש שעות הקאתי לתוך שקית, ודמיינתי את מותי בשמי פולין." 51 Ibid., 44. 
undermined her imagined but seemingly tangible future, but she surrenders to her childhood trauma as a second-generation child in particular. Poland is full of Holocaust memories and is therefore a place of death for Amalia. It is at the least not where she believes they could live happily ever after. Amalia prefers a house in Paris, but Hezi says that they already have one there and that it is time to build a new one in the former homeland of their parents. ${ }^{52}$

Hezi is obsessed with the Holocaust. His Parisian ex-girlfriend even calls him "the Holocauster." For him, too, his dream is fulfilled when he moves to the French capital for his studies. He had been learning French for several years with his parents' friend Wolf Katzenelnbogen, and when he finally arrives, he is full of excitement. However, the perspective of the historian and his professor with whom he has a good relationship provide him with deeper insights, and he starts to ask questions about the past. He was brought up with the narrative of the résistance and when he arrives in France, he accepts this perspective on history as a reality for a long time. However, with his growing obsession, he discovers more and more details until he finally bursts out: “'You are another people,' I told her [Solange, Hezi's Parisian girlfriend], 'you are a people wrapped in crème brûlée and spread in butter and chocolate, a people that covers up its sins with make-up and powder."'53

The idealized perception Hezi has of France in general, and of Paris in particular, is the result of the stories Wolf Katzenelnbogen tells him. The first French word he teaches the young boy is "amour" and the French teacher emphasizes that the military support for Israel comes from "le peuple français." 54 However, when Hezi finally lives in Paris and studies and teaches there on a daily basis, the spectacle ceases to be idealized. Moreover, as opposed to Amalia and the characters from the two novels discussed above, he does not flee to Paris in order to avoid the everyday reality of his Israeli life. Hence, the city neither plays a redemptive role for him, nor does it function as a blind spot in Hezi's personal narrative. He confronts the French people with their responsibility and makes clear that they participated in persecuting the Jews under the Nazi occupation. Nevertheless, the places of horror remain, even in Hezi's account, outside of Paris: Drancy on the one hand and Eastern Europe on the other.

Although Amalia and Hezi never live together in Paris, and Amalia's description of the city consists therefore only of fantasies, her perception of Paris as an

52 Ibid., 46.

"את עם אחר, אמרתי לה, 'את עם עטוף בקרם ברולה ומרוח בחמאה ושוקולד, עם שמכסה את חטאיו במייק-אפ 53

Ibid., 141.

54 Ibid., 118. 
ahistorical place is the most explicit among the three novels. Amalia's dreams are "kitschy," even more than Rivi's, but this is relativized by her sarcasm and Doron's ironic style of writing. In a certain way, the enormous discrepancy between Paris and Poland in Amalia's imagination contributes even more to the irony as does the fact that for Hezi, who has lived in Paris for many years already, the dark history beyond the façade comes to the surface. To Amalia, Paris means light not darkness, happiness not death, whereas Poland represents mass killing and is a country where every stone could be from a Jewish grave or the house their parents and grandparents were taken from.

\section{Conclusion}

All three protagonists, Molkho, Rivi, and Amalia, go to Paris in couples, though it does not seem so at first glance. Molkho travels alone, but does so in memory of his late wife. Therefore, she is in a sense "with him." Rivi and Yigal go there to be a regular couple at least for a few days, and Amalia and Hezi travel together and she envisions their life there, even if they do not stay in Paris. Outside of Paris, Amalia and Hezi are haunted by their parents' trauma, and their happiness fails even before Amalia leaves Poland to go back to Israel. Moreover, in all the three novels the voyage to Paris is only a short episode of the plot. However, it becomes clear that the voyage to Paris resembles an escape from the character's daily life as well as a blind spot. The latter is realized by portraying the city mostly in contrast to other places in Europe - Vienna and Berlin in Five Seasons, Poland in On the Brink of Something Beautiful, and Italy and Spain in Matisse Has the Sun in His Belly. The fact that the southern European countries are generally not the first associated with European-Jewish Holocaust memory and trauma does not necessarily diminish the meaning of Paris, but rather widens the space of an imaginary, positive, ahistorical Europe; although, in Katzir's novel, these places are of course portrayed as all but ahistorical from a cultural and artistic point of view. The places Rivi and Yigal see in Italy and Spain are, thus, left out of the traumatic Jewish experience as well and serve as romantic sites and historical blind spots. The fact that they never went to Poland together, where Yigal came from, speaks for itself. Central and Eastern Europe as well as Germany are those realms where most characters in Hebrew literature and Jewish Israelis and non-Israelis with a European background in general go to when they want to explore their family history and their ancestors' lives. Many of those places disappeared; they represent the erasing of history and come often with traumatic memories, although it is a sense of belonging that brings people there. The fear of disappearance is 
something rather characteristic for Central Europe and is deeply inscribed into the historical conscience of its small nations. This feeling has led to a distrust in history, as Milan Kundera argues in his essay, “The Tragedy of Central Europe.”55 This Central European notion of uncertainty and constant menace is, as he continues, a factor that constitutes European Jewish history even more. As opposed to this, we read in Katzir's novel of the notion that the buildings of Paris remain, however, indifferent and great with the assurance of centuries behind them. Thus, Paris attracts them through a longing for stability or even only an idealized image.

Europe is in general a place with a long past and an enormously complex history. A. B. Yehoshua talks to Bernard Horn about his love for the visible and touchable history: "When I think about the place itself, we don't have the past like the Europeans, like a Parisian, for example, who can go out into the street and touch a church that was built in the eighteenth century or the seventeenth century. Europeans can visit a library that holds old manuscripts and a whole physical environment. But we don't have the past in the present physically."56 This is the past Molkho sees in Versailles or the history for which Rivi loves the old houses. It is not the past of traumatic memories.

Some of the protagonists do have memories of Paris, but they are personal and mostly happy memories - as is the case with Molkho. Moreover, these memories are not embedded in a historical time. In general, it can be said that Paris is a place where time stands still for the characters: Rivi and Yigal pause for a few days in the development of their relationship that first ignites in Italy and then gets its first scratches in Spain. Molkho breathes for the first time after his wife died; he realizes that he will travel alone from now on and he needs this time to remember her. For Amalia, it is the thought of going to Paris that lets her imagine that time can stop, because for her time is the endless circle of Holocaust trauma and remembrance. The impression of a timeless Paris in Hebrew literature leads to the conclusion that it is a stable point in the chaotic European landscape of memory and therefore a historical blind spot, an area with no image detection. ${ }^{57}$ This is what happens to Molkho, Rivi, and Amalia in Paris. They are unable and often do not want to detect the image of history unlike at other European places and the fact, that all three novels are written in a rather realistic tone, does contribute to this effect since leaving out a specific chapter of Parisian

55 Milan Kundera, “The Tragedy of Central Europe,” in The New York Review of Books, April 26, 1986.

56 Horn, Facing the Fires, 106.

57 David M. Gamm, Daniel M. Albert, “Blind Spot,” in Encyclopaedia Britannica, accessed September 1, 2015. https://www.britannica.com/science/blind-spot. 
history becomes even more unique. The described perspective leads on the one hand to the characters' utopian ideas, and the impression that Paris seems to be a museum, exhibiting its own myths. Rivi and Yigal, for example, sit at the Closserie de Lilas at the tables of Henry Miller, Gertrude Stein, and Jean-Paul Sartre. And on the other hand, the alleged absence of history brings a feeling of security and stability.

Regarding the perception of the cityscape, Molkho explores Paris often from within buildings and houses, but the narrator mentions the typical boulevards. Except for that, the protagonist dwells in unremarkable streets "behind (!) the opera house" or visits the department stores. In Matisse Has the Sun in His Belly, Paris is described in much more picturesque terms, referring to specific Parisian characteristics like the typical houses with their black roof or a bistro situated on a street corner, as well as narrow streets between small shops and houses in the Latin Quarter. Amalia on the other hand never arrives in the city and she thinks first and foremost of the Eiffel Tower and the Arc de Triomphe when she imagines Paris. In other words, in her narrative there is neither urbanity nor a landscape. Moreover, she thinks of Paris as a city full of light as opposed to the darkness of Poland, whereas the weather throughout Molkho's voyage is everything but bright, and even Rivi sees a grey sky when looking out of the window the first morning. Thus, although the cityscape in Katzir's novel is much more romanticized than in that of Yehoshua, the narrator does not overly idealize his description. However, as opposed to the urban landscape at the center of his writing on Paris, for the characters of Yehoshua, Katzir, and Doron the emotional landscape is of much greater importance.

This emotional landscape emerges from the creation of a timeless space by the narrator; this timelessness is not necessarily a result of the absence of historical time as such, but refers mostly to the lack of commemoration of historical events connected to World War II and especially the Holocaust. This becomes even clearer when comparing the imagination of Paris to fictional writing on Berlin, Vienna, and Poland as I suggested above. Thus, the imagination of Paris is characterised by a historical blind spot the characters are longing for: it is clear that the French capital is neither their Heimat nor are they permanently in exile, but the imagined realm provides them with a temporal spiritual homeland free of a traumatic past and its memories. 


\section{Bibliography}

Banbaji, Amir. "הבישלונות של מולכו: ראליזם, מודרניזם, מזרחיות מצטלבים: עיונים ביצירת א"ב In יהושע. Edited by Amir Banbaji, Nitza Ben-Dov, and Zavi Shamir, 173-194. Tel Aviv: Hakibbutz Hameuchad, 2010.

Ben-Atiya, Yuval. "תמונות פריזאיות'. דיוקן פריס בשירה העברית בין שתי מלחמות העולם'." M.A. thesis, Tel Aviv University, 2002.

Ben-Dov, Nitza. “על א"ב יהושע ויצירתו." In מבטים מצטלבים: עיונים ביצירת א"ב יהושע. Edited by Amir Banbaji, Nitza Ben-Dov, and Zavi Shamir, 9-13. Tel Aviv: Hakibbutz Hameuchad, 2010.

Benjamin, Walter. Charles Baudelaire: A Lyric Poet in the Era of High Capitalism. Translated by Harry Zohn. London/New York: Verso, 1997.

Benjamin, Walter. "Paris: Capital of the XIX. Century.” Perspecta 12 (1969): 163-172.

Benjamin, Walter. "Paris die Hauptstadt des XIX. Jahrhunderts." In Walter Benjamin. Gesammelte Schriften. Edited by Rolf Tiedemann, V: 45-59. Frankfurt a. M.: Suhrkamp, 1991.

Benjamin, Walter. "Pariser Passagen II." In Walter Benjamin. Gesammelte Schriften. Edited by Rolf Tiedemann, V: 1044-1059. Frankfurt a. M.: Suhrkamp, 1991.

Certeau, Michel de. The Practice of Everyday Life. Translated by Steven Rendall. Berkeley/Los Angeles/London: University of California Press, 1984.

Domb, Risa. "Home and Abroad: Israel and Europe in Hebrew Fiction of the 1980s." Israel Affairs 1, no. 2 (1994): 323-333.

Doron, Lizzie. התחלה של משהו יפה. Jerusalem: Keter, 2007.

Gamm, David M., and Daniel M. Albert. "Blind Spot.” Encyclopaedia Britannica. https://www. britannica.com/science/blind-spot. Accessed September 1, 2015.

Gold, Nili. "The Topography of the City and the Body: Yehudit Katzir's Haifa." Hebrew Studies 47 (2004): 281-294.

Hollwich, Fritz. Ophthalmology: A Short Textbook. Translated by Frederick C. Blodi. 2nd ed. Stuttgart/New York: Georg Thieme Verlag/Thieme Stratton, 1985.

Horn, Bernard. Facing the Fires. Conversations with A.B. Yehoshua. Syracuse: Syracuse University Press, 1997.

Katzir, Judith. למאטיס יש את השמש בבטן. Tel Aviv: Hakibbutz Hameuchad, 1995.

Kok Escalle, Marie-Christine. Introduction to Paris: De l'Image à la Mémoire. Représentations Artistiques, Littéraires, Socio-Politiques. Edited by Marie-Christine Kok Escalle, 1-7. Faux Titre: Etudes de Langue et Littérature Françaises Publiées 122. Amsterdam/Atlanta: Rodopi, 1997.

Kok Escalle, Marie-Christine, ed. Paris, de l'Image à la Mémoire: Représentations Artistiques, Littéraires, Socio-Politiques. Amsterdam/Atlanta: Rodopi, 1997.

Kundera, Milan. “The Tragedy of Central Europe.” The New York Review of Books, April 26, 1986.

Lauster, Martina. “Walter Benjamin's Myth of the 'Flâneur'.” The Modern Language Review 102, no. 1 (2007): 139-156.

McMahon, Joseph H. Paris in Literature. New Haven: Yale University Press, 1964.

Milner, Iris. קרעי עבר. ביוגרפיה, זהות וזיכרון בסיפורת הדור השני. Tel Aviv: Am Oved, 2003.

Morahg, Gilead. "Reality and Symbol in the Fiction of A. B. Yehoshua." Prooftexts 2, no. 2 (1982): 179-196.

Müller, Judith. "Auf der Suche nach dem letzten Europäer in Judith Katzirs Matisse hat die Sonne im Bauch - Eine israelische Nebenfigur aus einer Welt von Gestern." Germanica Revues. Regards croisés sur l'Europe et les voisins européens 56 (2015): 15-26. 
Netanel, Lilach. המולדת הישנה. Jerusalem: Keter, 2014.

Nora, Pierre. Les lieux de mémoire. Paris: Gallimard, 1997.

Ofrat, Gideon. פאריז-תל אביב. הקשר הצרפתי של האמנות הישראלית. מאמרים ורשימות. Tel Aviv: Ofer Levi Foundation for Israeli Art, 2015.

Rubins, Maria. "The Diasporic Canon of Russian Poetry: The Case of the Paris Note." In Twentieth-Century Russian Poetry. Reinventing the Canon. Edited by Katharine Hodgson, Joanne Shelton, and Alexandra Smith, 289-328. Cambridge: Open Book Publishers, 2017.

Schwartz, Marcy E. Writing Paris: Urban Topographies of Desire in Contemporary Latin American Fiction. Albany: State University of New York Press, 1999.

Starr, Deborah A., and Sasson Somekh, eds. Mongrels or Marvels. The Levantine Writings of Jacqueline Shohet Kahanoff. Stanford: Stanford University Press, 2011.

Thompson, Victoria E. “Telling 'Spatial Stories': Urban Space and Bourgeois Identity in Early Nineteenth Century Paris.” The Journal of Modern History 75, no. 3 (2003): 523-556.

Wakeman, Rosemary. The Heroic City: Paris 1945-1958. Chicago: University of Chicago Press, 2009.

Wardi, Dina. Memorial Candles. Children of the Holocaust. Translated by Goldblum Naomi. London/New York: Routledge, 1992.

Westerwelle, Karin. “Paris: Urbanität, Entgrenzung, Flüchtigkeit.” In Handbuch Literatur \& Raum. Edited by Jörg Dünne and Andreas Mahler, 431-441. Berlin a.o: De Gruyter, 2015.

Willms, Johannes. Paris. Hauptstadt Europas 1800-1914. Munich: C.H. Beck, 2000.

Yehoshua, Abraham B. מולכו. Tel Aviv: Hakibbutz Hameuchad, 1987.

Yudkin, Leon I. “Memorialization in New Fiction.” World Literature Today 72, no. 3 (1998): 485-492.

Zweig, Stefan. Die Welt von Gestern. Erinnerungen eines Europäers. Frankfurt am Main: Fischer Taschenbuch Verlag, 2012. 